\title{
Biochemical and histochemical effects of perorally applied endotoxin on intestinal mucin glycoproteins of the common carp Cyprinus carpio
}

\author{
Henner Neuhaus ${ }^{1, *}$, Marian van der Marel $^{1}$, Nancy Caspari ${ }^{1}$, Wilfried Meyer ${ }^{2}$, \\ Marie-Luise Enss ${ }^{3}$, Dieter Steinhagen ${ }^{1}$ \\ ${ }^{1}$ Fish Disease Research Unit, Centre of Infectious Diseases, University of Veterinary Medicine Hannover, Bünteweg 17 , \\ 30559 Hannover, Germany \\ ${ }^{2}$ Institute of Anatomy, University of Veterinary Medicine Hannover, Bischofsholer Damm 15, 30173 Hannover, Germany \\ ${ }^{3}$ Institute for Laboratory Animal Science and Animal Facility, Medical School Hannover, Carl-Neuberg-Str. 1, \\ 30625 Hannover, Germany
}

\begin{abstract}
Mucins are high molecular weight glycoproteins produced by goblet cells and secreted on mucosal surfaces. We investigated biochemical and histochemical properties of intestinal mucins of virus- and parasite-free common carp Cyprinus carpio in response to a single peroral application of endotoxin (lipopolysaccharide $=$ LPS). Intracellular mucins were quantified histochemically by their carbohydrate content and characterized by specific, lectin-based methods. In addition, secreted epithelial (intracellular) and luminal (extracellular) mucins were isolated and separated by downward gel filtration. Carbohydrate and protein content were determined photometrically. Subsequently, terminal glycosylation was characterized by a lectin-binding assay. A peroral endotoxin application altered intestinal secretion and composition of intestinal mucin glycoproteins in common carp. A statistically significant decrease in mature luminal mucins was demonstrated, linked to a new biosynthesis of intracellular mucin glycoproteins. Simultaneous changes in the glycosylation pattern of isolated mucins were found. The intestinal mucosal system is purported to provide a removal mechanism for bacterial noxes by increasing secretion of mucins inducing a flushing-out effect, in combination with altered glycosylation patterns that change adhesion properties. Consequently, pseudofaeces of fish, which are a common sign of intestinal parasitical infections, may also be interpreted as an elimination mechanism for strong bacterial noxes.
\end{abstract}

KEY WORDS: Carp $\cdot$ Mucus $\cdot$ Intestinum $\cdot$ Endotoxin $\cdot$ Lipopolysaccharide

\section{INTRODUCTION}

Intestinal tissue of vertebrates is exposed continually to challenges from bacteria, parasites, viruses and toxins from the luminal contents. Intestinal epithelial cells are protected from pathogens by a mucus layer, which covers the intestinal epithelium in vertebrates such as mammals and fish (Shephard 1994). Mucin glycoproteins ('mucins') are considered to be the major component of this protective biofilm, which is produced by goblet cells that are scattered in many epithelial systems of aquatic vertebrates, particularly in the gut.
High molecular weight glycoproteins (HMGs) form a water-insoluble layer of adherent mucus on epithelial cells. HMGs have a high content of oligosaccharides that are believed to mediate adhesion of microbial pathogens (Carlstedt et al. 1985, Karlsson et al. 1991, Bordas et al. 1998, Perez-Vilar \& Hill 1999, Moncada et al. 2003) and protect the glycoproteins from degradation by proteases of microbial origin.

Although all fish surfaces are covered with this mucus layer, knowledge of piscine mucins and their responses to noxes is scarce. Based on histochemical data, the number and content of intestinal goblet cells 
in fish are considered to be similar to those of mammals. As in mammals, there is production of secretory vesicles with neutral, acidic or sulphated glycoproteins (Shephard 1994, Bosi et al. 2005). Histological and histochemical studies also indicate that fishes with parasitic infections (like infected mammals) exhibit goblet cell hyperplasia and hypertrophy, whereby as a chronic reaction their intracellular mucins shift towards acidic and sulphated glycoprotein types (George \& Nadakal 1981, Dezfuli et al. 2002, Bosi et al. 2005).

However, to our knowledge little information is available on the biochemical composition of piscine glycoproteins and their response to enteric bacterial infections. We mimicked bacterial infection by an oral application of endotoxin. Endotoxins are lipopolysaccharide (LPS)-protein complexes synthesized mainly by gram-negative bacteria. LPS is an integrated part of the bacterial membrane. Endotoxin has, at least in mammals, a local and systemic immune-inducing function in inflammation reactions (Raetz 1990, Raetz \& Whitfield 2002). Toxic effects are mainly mediated by cell receptors (TLR-4) and leucocyte mediators; however, there are numerous key differences between fish and mammals. In many in vitro studies on cells of lower vertebrates, such as fish, extremely high concentrations of LPS ( $\mu \mathrm{g} \mathrm{ml} \mathrm{m}^{-1}$ ) have been used to induce immune responses. In fish (in contrast to mammals), some cell integrins and molecules for signal transduction are totally missing, or have yet to be identified (Iliev et al. 2005).

Here, intestinal goblet cells of the common carp were characterized primarily by biochemical analyses of responses to single oral endotoxin applications. Additionally, histochemical methods were applied to the analysis of goblet cell carbohydrate contents.

\section{MATERIALS AND METHODS}

Carp specimens. Parasite- and virus-free sibling carp $(\mathrm{n}=50)$ from a single cross $(\mathrm{E} 20 \times$ R8, Wageningen Agricultural University, The Netherlands) were used (Wiegertjes et al. 1995). The carp were raised and kept in filtered recirculated tap water. For all experiments, 12 to 18 mo old carp with a mean $( \pm \mathrm{SE})$ body weight of $76.36 \mathrm{~g}( \pm 12.94 \mathrm{~g})$ and a mean $( \pm \mathrm{SE})$ length of $14.09 \mathrm{~cm}( \pm 0.92 \mathrm{~cm})$ were used. The carp were placed in a $400 \mathrm{l}$ tank with filtered tap water $5 \mathrm{~d}$ before applying endotoxin; the fish were starved to reduce faeces on intestinal mucus. For the oral application of endotoxin (150 $\mathrm{Mg} \mathrm{g} \mathrm{g}^{-1}$ bodyweight dissolved in phosphate-buffered saline, PBS; LPS of Escherichia coli O55:B5; Sigma) via intubation, the carp were anaesthetized by adding $150 \mathrm{mg} \mathrm{l}^{-1}$ tricaine (Sigma) and weighed. For sampling, carp were killed by bath immersion with $500 \mathrm{mg} \mathrm{l}^{-1}$ tricaine and subsequently dissected. The complete intestinal tract from pseudogaster to anus was removed, weighed and kept on ice. Samples were collected from 8 endotoxin-treated carp and from 2 carp treated with PBS on Days 1, 2, 3, 5 and 8 after intubation.

Histology and histochemistry. For histological examination, $4 \mathrm{~mm}$ long gut samples were taken ( $\mathrm{n}=$ $4 \mathrm{~d}^{-1}$ ) $4 \mathrm{~cm}$ behind the pseudogaster and fixed in Bouin's solution. The samples were dehydrated and embedded in paraffin wax. Sections $5 \mu \mathrm{m}$ thick were stained with haematoxylin-eosin (H\&E), and with alcian blue 8GX pH 1 (AB1.0) at pH 2.5 (AB2.5), as well as with AB2.5/periodic acid-Schiff (AB-PAS) for the detection of mucin carbohydrates. The AB1.0 method stains sulphated glycoconjugates; the AB-PAS reaction visualises neutral and acidic glycoconjugates (Pearse 1972, Brooks et al. 1997, Table 1). In addition, terminal mucin sugar residues were characterized with various biotinylated lectins $\left(10 \mu \mathrm{g} \mathrm{ml}^{-1}\right.$ in $0.1 \mathrm{M} \mathrm{PBS,} \mathrm{pH} \mathrm{7.2,}$ $30 \mathrm{~min}$ at room temperature; lectins and their sugar specificities are listed in Table 1). Lectin binding was visualised with peroxidase (PO), conjugated streptavidin and a diamino-benzidine-hydrogen peroxidase system (DAB, Biogenex, Super Sensitive System) according to the instructions of the manufacturer.

Isolation of HMGs. Intestines of carp (mean $\pm \mathrm{SE}$ intestinal weight of $1.06 \pm 0.2 \mathrm{~g}$ ) were opened longitudinally and cut into small pieces of 3 to $4 \mathrm{~mm}$. Subsequently, secreted luminal glycoproteins were isolated with isolation medium as described by Enss et al. $(1996 a, b)$. In brief, tissue pieces were incubated for $20 \mathrm{~min}$ in $100 \mathrm{ml}$ isolation buffer containing antibiotics and protease inhibitors. The isolation buffer was collected, centrifuged for $30 \mathrm{~min}$ at $12000 \times g$, and the supernatant was collected and frozen at $-20^{\circ} \mathrm{C}$ until further processing. Epithelial glycoproteins were released from goblet cells by subsequent incubation of the tissue pieces in a buffer containing antibiotics, protease inhibitors and EDTA for $30 \mathrm{~min}$ (Enss et al. 1996a,b). Goblet cells were disrupted by means of an ultrasonic unit (Ultra Turrax T8, IKA-Werke). The suspension was centrifuged at $10000 \times g$ for $30 \mathrm{~min}$, and the supernatant was collected and homogenised by gentle stirring. All samples were concentrated by ultrafiltration (Amicon; exclusion limit $30000 \mathrm{Da}$ ) to a final volume of $2 \mathrm{ml}$. Concentrated mucus samples were subjected to downward gel filtration on a $34 \times$ $0.9 \mathrm{~cm}$ Sepharose CL-4B column (Sigma; flow rate $5.2 \mathrm{ml} \mathrm{h}^{-1}$, fraction size $1.3 \mathrm{ml}, 40$ fractions). For calibration, pig gastric mucin (PGM; molecular weight $>2000 \mathrm{kDa}$ ), thyroglobulin (molecular weight $=$ $670 \mathrm{kDa}$ ), ferritin (molecular weight $=450 \mathrm{kDa}$ ) and bovine serum albumin (BSA, molecular weight $=69 \mathrm{kDa})$ were used (Sigma). Aliquots of each fraction were 
Table 1. Cyprinus carpio. Histochemical and lectin histochemical characterization of intestinal, intracellular goblet cell mucin carbohydrates by charge (PAS, AB-PAS, AB1.0, AB2.5) and sugars via lectin linkage (ConA, DBA, MAA, PNA, RCA, SNA, UEA I, WGA) after application of endotoxin (staining reaction: $1=$ weak $_{;} 2=$ weak to moderate $3=$ moderate; $4=$ moderate to strong, $5=$ strong reaction); ctr: control (application of phosphate buffered solution)

\begin{tabular}{|c|c|c|c|c|c|c|c|c|}
\hline \multirow[t]{2}{*}{ Acronym } & \multirow[t]{2}{*}{ Staining method } & \multirow[t]{2}{*}{$\begin{array}{l}\text { Binding } \\
\text { specificity }\end{array}$} & \multicolumn{6}{|c|}{$\begin{array}{l}\text { Goblet cell histochemical staining intensity } \\
\text { after endotoxin application }\end{array}$} \\
\hline & & & $\mathrm{ctr}$ & Day 1 & Day 2 & Day 3 & Day 5 & Day 8 \\
\hline \multicolumn{9}{|c|}{ Conventional histochemistry } \\
\hline PAS & Periodic-acid Schiff & Neutral glycoproteins & 3 & $2-3$ & $1-2$ & $1-2$ & $2-3$ & $2-3$ \\
\hline AB-PAS & Alcian blue PAS & Neutral and acidic glycoproteins & 3 & $2-3$ & 3 & $2-3$ & 3 & 3 \\
\hline AB1.0 & Alcian blue pH 1.0 & Sulphated glycoproteins & $1-2$ & 2 & 2 & 2 & $1-2$ & $1-2$ \\
\hline $\mathrm{AB} 2.5$ & Alcian blue $\mathrm{pH} 2.5$ & Acidic glycoproteins & $1-2$ & $1-2$ & $1-2$ & 2 & $1-2$ & 2 \\
\hline \multicolumn{9}{|c|}{ Lectin histochemistry } \\
\hline ConA & Canavalia ensiformis & $\alpha$-D-mannose & 3 & $2-3$ & $2-3$ & $1-2$ & 3 & $2-3$ \\
\hline DBA & Dolichos biflorus & N-acetyl- $\alpha$-D-galactosamine & $2-3$ & $3-4$ & $3-4$ & $3-4$ & $4-5$ & $3-4$ \\
\hline MAA & Maackia amurensis & Neuraminic-acid- $\alpha-2-3$-galactose & $1-2$ & $1-2$ & $1-2$ & 1 & $1-2$ & $1-2$ \\
\hline PNA & Arachis hypogyea & $\beta$-D-galactose & $2-3$ & 3 & 4 & $4-5$ & 3 & 3 \\
\hline RCA & Ricinus communis & $\mathrm{N}$-acetyl $\beta$-D-galactosamine & $2-3$ & $4-5$ & $4-5$ & $2-3$ & $2-3$ & $2-3$ \\
\hline SNA & Sambucus nigra & Neuraminic-acid- $\alpha-2-6$-galactose & 2 & 2 & $2-3$ & 2 & $2-3$ & 2 \\
\hline UEA I & Ulex europaeus & Fucose- $\alpha 1-2$-galactose & $1-2$ & $1-2$ & 1 & $1-2$ & 1 & $1-2$ \\
\hline WGA & Triticum vulgaris & $\mathrm{N}$-acetyl $\beta$-D-glucosamine & $1-2$ & $1-2$ & $1-2$ & $2-3$ & $2-3$ & $1-2$ \\
\hline
\end{tabular}

determined for carbohydrate content by the PAS reaction (absorbance at $550 \mathrm{~nm}$ ) and for protein content by the Bradford reaction (absorbance at $580 \mathrm{~nm}$; BMG) (Dubois et al. 1956, Bradford 1976, Enss et al. 1992). Glycoprotein content was calculated (CGC) in mg HMG g ${ }^{-1}$ gut, with lyophilised pig gastric mucin as a standard via PAS reaction. Endotoxin contents of pooled mucin glycoprotein fractions were determinated with the Limulus test (Morita et al. 1978).

Determination of the terminal glycosylation pattern in mucin glycoproteins via lectin-binding assay. Aliquots of mucin glycoprotein fractions (200 $\mu \mathrm{l})$ from 4 carp from each sampling day were incubated overnight at room temperature in 96-well microtiter plates (Nunc Maxisorb). Subsequently, nonspecific binding sites were blocked with $1 \%$ BSA in PBS, and then incubated with biotin labelled lectins $\left(10 \mu \mathrm{g} \mathrm{ml}^{-1}\right.$ in $0.1 \mathrm{M}$ PBS) for $30 \mathrm{~min}$ at room temperature. The following lectins were used: Concanavalia ensiformes (Con A), Dolichos biflorus (DBA), Ricinus communis (RCA), Sambucus nigra (SNA) and Ulex europaeus I (UEA I) (see Table 1). Lectin binding was visualised by subsequent incubation with streptavidin-horseradishperoxidase for $30 \mathrm{~min}$ at room temperature and orthophenyl-diamine (OPD) (DAKO Chemicals). After $15 \mathrm{~min}$, the reaction was stopped by addition of $0.5 \mathrm{M}$ sulphuric acid, and the optical density (OD) was read in a microplate reader (BMG) at $485 \mathrm{~nm}$ (Enss et al. 1995, 1996a,b). Carp from sampling Days 2 and 3 treated with PBS served as controls.

Statistics. Unless otherwise indicated, OD is expressed as median value and 25 to $75 \%$ quartiles. Analysis of variance (ANOVA) and Dunn's multiple comparison tests (treatments versus control group) were performed. Differences were considered significant at $\mathrm{p}<$ 0.05 . For some sampling points, the data were not statistically significant because of individual variations in the carp used. Urlaub et al. (1998) as well as Enss et al. $(1996 a, b)$ also found high individual variations in rats and mice. In concurrence with these studies, if data were not statistically significant, they were used as indicators of trends in mucin composition (Table 2).

\section{RESULTS}

\section{Carp specimens}

All fish appeared healthy throughout the study, no clinical alterations were observed during maintenance.

\section{Histology and histochemistry}

The intestinal mucosa of control carp was formed by a continuous lining of columnar enterocytes. Goblet cells were located regularly in this epithelium between the enterocytes. Most goblet cells of controls had a rounded, thick appearance, and were filled with visible carbohydrate contents. Glycoprotein staining intensity varied from very weak to moderate, indicating the presence of neutral, acidic and sulphated glycoconjugates (Fig. 1, Table 1). Goblet cells responded in 2 different ways to AB 1.0 (staining of acid glycoconjugates). One population of cells was stained rather 
Table 2. Cyprinus carpio. (a) Epithelial and (b) luminal glycoproteins isolated from intestinal goblet cells after administration of endotoxin. OD: optical density; CGC: calculated glycoprotein content; PI: Peak I, fractions with glycoproteins >2000 kDa; PII: Peak II, fractions with glycoproteins between 70 and $700 \mathrm{kDa}$; TA: transition area, fractions with molecules between 700 and 2000 kDa (see Figs. 1 \& 2). ctr: control $^{*}$ p $<0.05$

\begin{tabular}{|c|c|c|c|c|c|c|c|c|c|}
\hline & \multicolumn{2}{|c|}{$\begin{array}{l}\text { Glycoproteins of } \\
\text { ctr carp (OD) }\end{array}$} & \multirow[t]{2}{*}{$\begin{array}{c}\text { CGC } \\
\left.\text { (mg g }{ }^{-1} \text { gut }\right)\end{array}$} & \multicolumn{6}{|c|}{$\begin{array}{c}\text { Content after application of endotoxin } \\
\text { (\% of control) }\end{array}$} \\
\hline & Median & Quartiles & & $\mathrm{ctr}$ & Day 1 & Day 2 & Day 3 & Day 5 & Day 8 \\
\hline \multicolumn{10}{|l|}{ (a) Epithelial } \\
\hline \multicolumn{10}{|l|}{ PI (fraction 7-10) } \\
\hline Carbohydrate & 1.19 & $0.82 / 1.56$ & 0.25 & 100 & 80 & 97 & $150^{*}$ & $165^{*}$ & $161^{*}$ \\
\hline Protein & 1.35 & $1.07 / 1.81$ & & 100 & $154^{*}$ & 103 & $167^{*}$ & $200^{*}$ & 93 \\
\hline \multicolumn{10}{|c|}{ TA (fraction 11-15) } \\
\hline Carbohydrate & 0.54 & $0.30 / 0.76$ & 0.11 & 100 & 94 & $154^{*}$ & $163^{*}$ & $174^{*}$ & $167^{*}$ \\
\hline Protein & 1.09 & $0.80 / 1.52$ & & 100 & $214^{*}$ & 126 & $177^{*}$ & $189^{*}$ & $139^{*}$ \\
\hline \multicolumn{10}{|c|}{ PII (fraction 16-22) } \\
\hline Carbohydrate & 0.43 & $0.08 / 0.61$ & 0.09 & 100 & 128 & $207^{*}$ & $181^{*}$ & $293^{*}$ & 84 \\
\hline Protein & 2.81 & $2.34 / 3.67$ & & 100 & 102 & $57^{*}$ & $50^{*}$ & 105 & $65^{*}$ \\
\hline \multicolumn{10}{|c|}{ Total (fraction 1-40) } \\
\hline Carbohydrate & 2.81 & $1.05 / 4.36$ & 0.59 & 100 & $106^{*}$ & $163^{*}$ & $226^{*}$ & $223^{*}$ & $155^{*}$ \\
\hline Protein & 7.52 & $5.23 / 10.53$ & & 100 & $138^{*}$ & $92^{*}$ & 108 & $146^{*}$ & 82 \\
\hline \multicolumn{10}{|l|}{ (b) Luminal } \\
\hline \multicolumn{10}{|l|}{ PI (fraction $7-10$ ) } \\
\hline Carbohydrate & 3.11 & $2.57 / 3.86$ & 0.66 & 100 & 75 & $35^{*}$ & $60^{*}$ & $80^{*}$ & 84 \\
\hline Protein & 1.48 & $0.98 / 2.03$ & & 100 & 105 & 77 & 95 & 117 & 98 \\
\hline \multicolumn{10}{|c|}{ TA (fraction 11-15) } \\
\hline Carbohydrate & 1.26 & $1.02 / 1.50$ & 0.27 & 100 & $228^{*}$ & 79 & 118 & $168^{*}$ & $189^{*}$ \\
\hline Protein & 3.84 & $2.62 / 5.02$ & & 100 & $159^{*}$ & $198^{*}$ & 117 & 106 & 66 \\
\hline \multicolumn{10}{|c|}{ PII (fraction 16-22) } \\
\hline Carbohydrate & 3.33 & $2.73 / 3.77$ & 0.71 & 100 & 92 & $57^{*}$ & $68^{*}$ & 93 & 96 \\
\hline Protein & 16.94 & $13.97 / 19.39$ & & 100 & $74^{*}$ & $73^{*}$ & $88^{*}$ & $69^{*}$ & $77^{*}$ \\
\hline \multicolumn{10}{|c|}{ Total (fraction 1-40) } \\
\hline Carbohydrate & 11.26 & $7.62 / 14.78$ & 2.39 & 100 & 94 & $45^{*}$ & $69^{*}$ & $88^{*}$ & 117 \\
\hline Protein & 33.01 & $24.81 / 41.38$ & & 100 & 91 & 88 & 91 & $74^{*}$ & 92 \\
\hline
\end{tabular}

weakly and a second population showed a stronger staining reaction. Lectin staining of goblet cell content for specific carbohydrates in control fish produced weak reactions with UEA I indicating fucose, WGA indicating $\mathrm{N}$-acetyl- $\beta$-glucosamine, and MAA indicating neuraminic-acid- $\alpha-2-3$-galactose; there were generally weak to moderate reactions with DBA indicating $N$-acetyl- $\alpha$-galactosamine, PNA indicating $N$-acetyl- $\beta$ 1-3-galactosamine, SNA indicating neuraminic-acid$\alpha$-2-6-galactose, and RCA indicating N-acetyl- $\beta$ galactosamine, and a moderate reaction with Con $\mathrm{A}$ indicating mannose (Fig. 2, Table 1).

No significant changes in goblet cell number and general carbohydrate histochemistry were observed in response to endotoxin treatment. Goblet cell shape generally changed slightly to a smaller and narrower appearance than in the controls by Day 1 post application (p. appl.) of endotoxin. There were, additionally, slight alterations in the lectin-binding pattern of goblet cell content. Mucin glycoproteins had a stronger binding reaction with RCA ( $\beta$-D-galactosamine) by Days 1 and 2 , with PNA ( $\beta$-D-galactose) by Days 2 and 3, with WGA ( $\beta$-D-glucosamine) by Day 3 , and with DBA ( $\alpha$-D- galactosamine) by Day 5 p. appl. Con A (mannose) had an increasing reaction by Days 2 and 5 p. appl., with a weaker binding by Day 3 p. appl. There was no cell infiltration into the tela submucosa throughout the study (Figs. $1 \& 2$ ).

\section{Isolation of mucin glycoproteins/HMGs}

We were able to isolate epithelial and luminal glycoproteins separately. When we monitored fractions from downward gel filtration for protein and carbohydrate contents, a biphasic elution profile was obtained (Figs. 3 \& 4). Among epithelial and luminal mucin glycoproteins, large molecules with a molecular weight $>2000 \mathrm{kDa}$ were eluted in a first peak (PI), and molecules in the range of 70 to $700 \mathrm{kDa}$ were eluted in a second peak (PII). Between these peaks, a transition area (TA) of fractions with a lower amount of glycoproteins was found. From the intestines of controls, epithelial glycoproteins were isolated at a concentration of $0.59 \mathrm{mg} \mathrm{g}^{-1}$ gut weight, and luminal glycoproteins at a concentration of $2.93 \mathrm{mg} \mathrm{g}^{-1}$ gut weight 


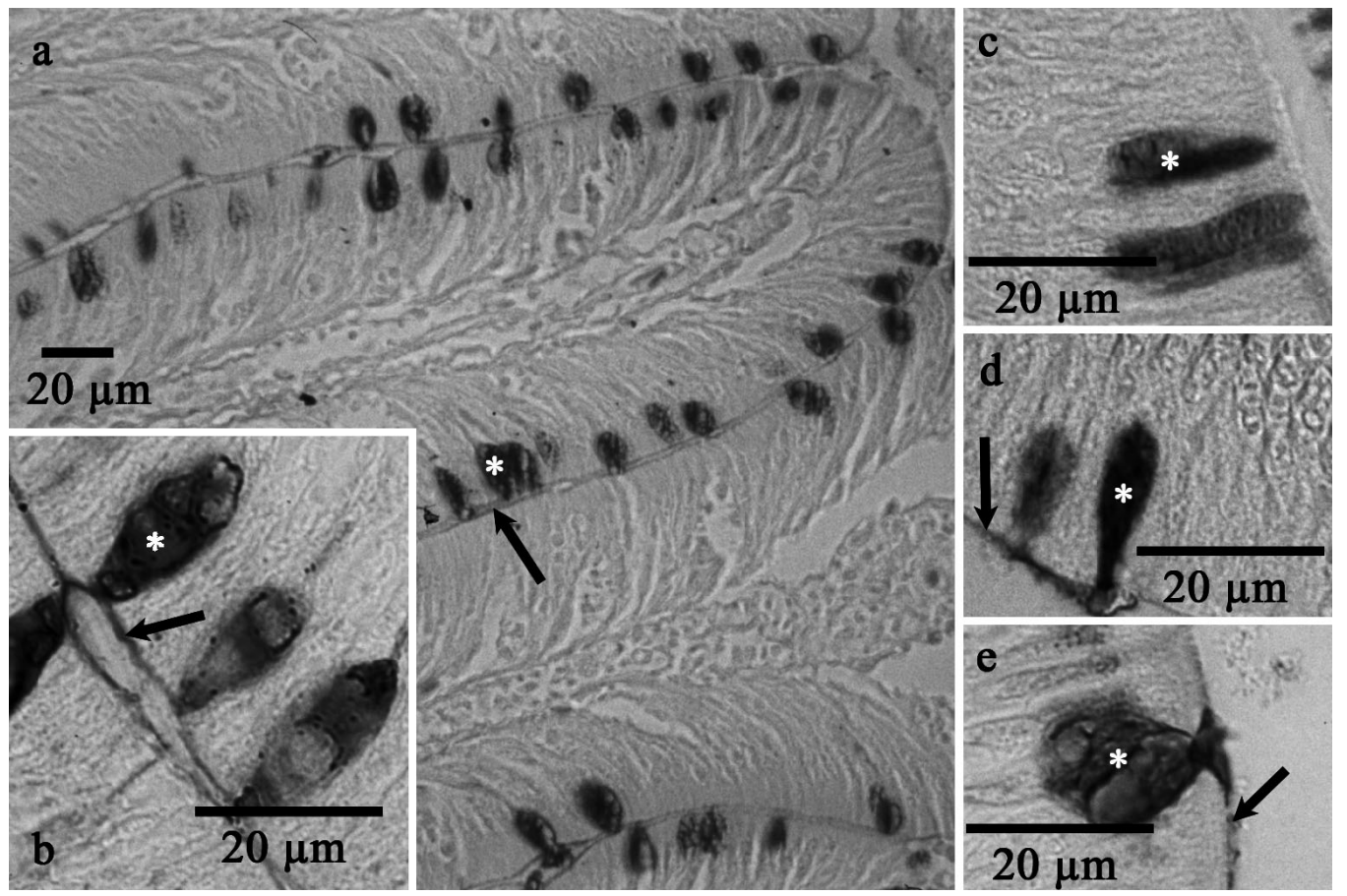

Fig. 1. Cyprinus carpio. General carbohydrate histochemical staining of the intestinal mucosa: (a) AB2.5 control, (b) AB-PAS control, (c) AB2.5 Day 1 post application, (d) AB1.0 Day 2 post application, (e) PAS Day 5 post application. Goblet cells (*) and mucus layer (arrows) covering the intestinal mucosa have positive, intense staining. See Table 1 for definition of stain acronyms

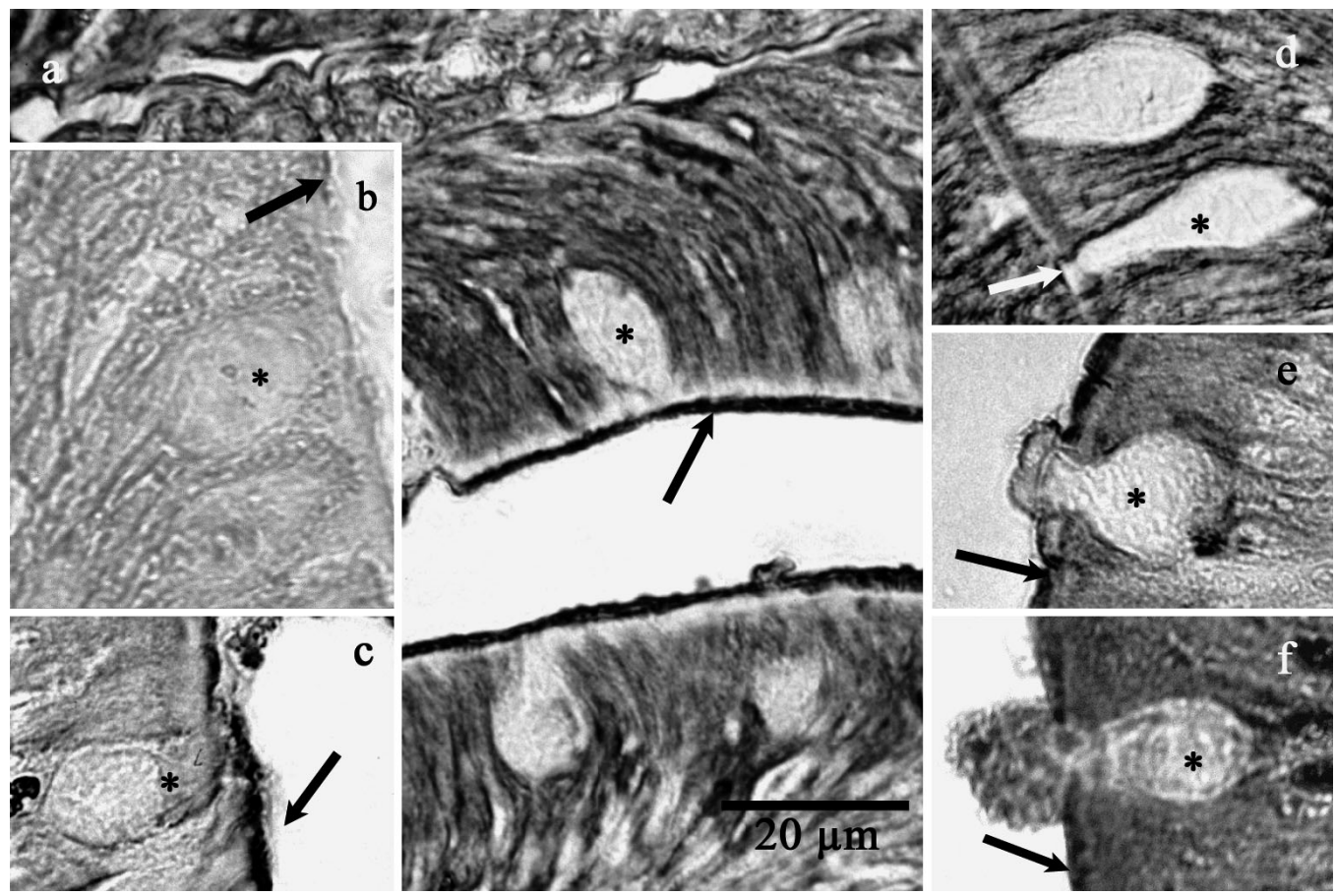

Fig. 2. Cyprinus carpio. Lectin histochemical staining of goblet cells, positive for the intestinal mucus layer (arrows). (a) DBA Day 3 post application, (b) PNA Day 2 post application, (c) RCA Day 2 post application, (d) UEA I Day 2 post applictation, (e) WGA Day 2 post application, (f) ConA Day 2 post application. Glycoprotein contents of goblet cells (*) showed a very weak (d) to moderate/strong $(\mathrm{b}, \mathrm{c})$ positive staining (see Table 1 for data and definitions of stain acronyms). All panels to the same scale as (a) 
Day 3 p. appl.
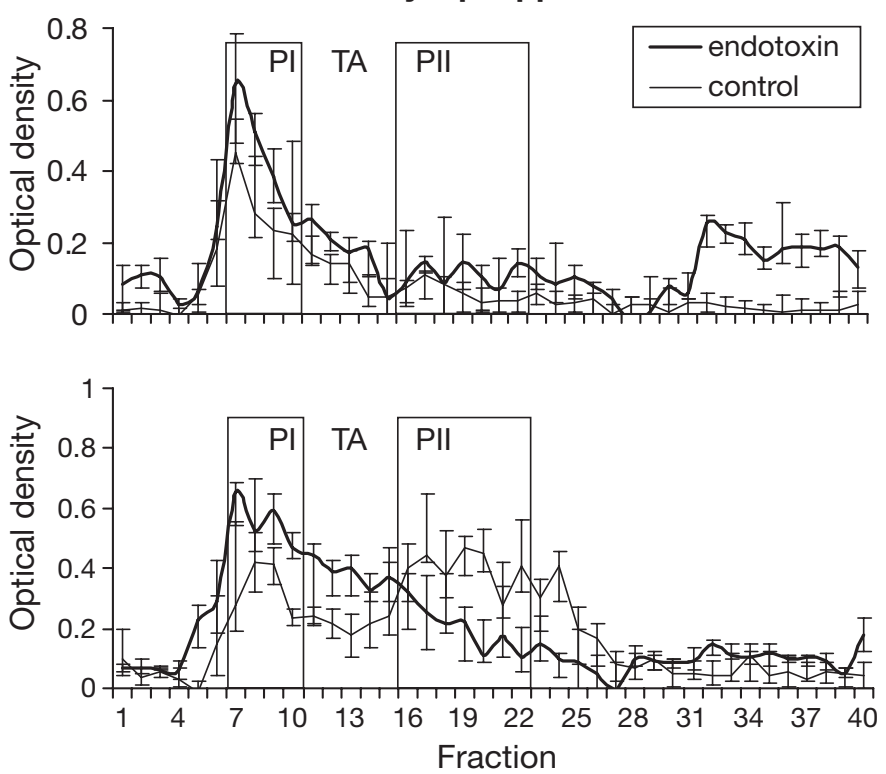

Day 5 p. appl.
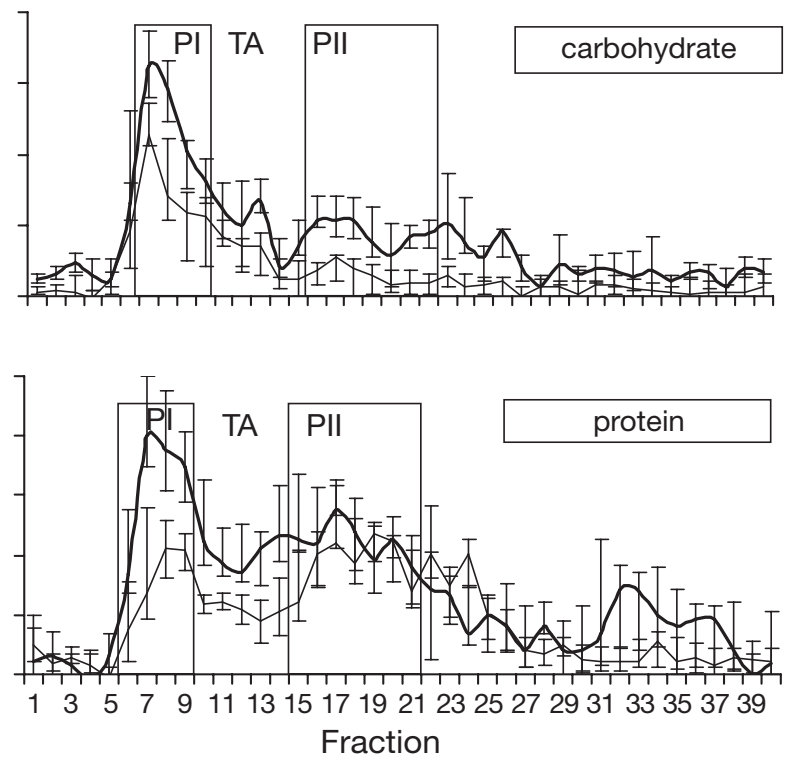

Fig. 3. Cyprinus carpio. Elution profiles of epithelial glycoproteins from the gut ( $\mathrm{g}^{-1}$ gut weight) isolated on a Sepharose CL4B column (fraction volume: $1.3 \mathrm{ml}$ ) by Days 3 and 5 after a single, peroral application of endotoxin, as described in 'Materials and methods'. p.appl: post application. Carbohydrate content was monitored by periodic acid-Schiff reaction (PAS), and protein content by the Bradford-assay. Medians and 25th-75th percentiles of samples from 8 individuals are shown. PI: Peak I, glycoproteins exceeding $2000 \mathrm{kDa}$; PII: Peak II, elution fractions with glycoproteins between 70 and $700 \mathrm{kDa}$; TA: transition area, elution fractions with molecules between 700 and $2000 \mathrm{kDa}$ (control = oral application of phosphate buffered solution, pool from all sample days)

Day 2 p. appl.
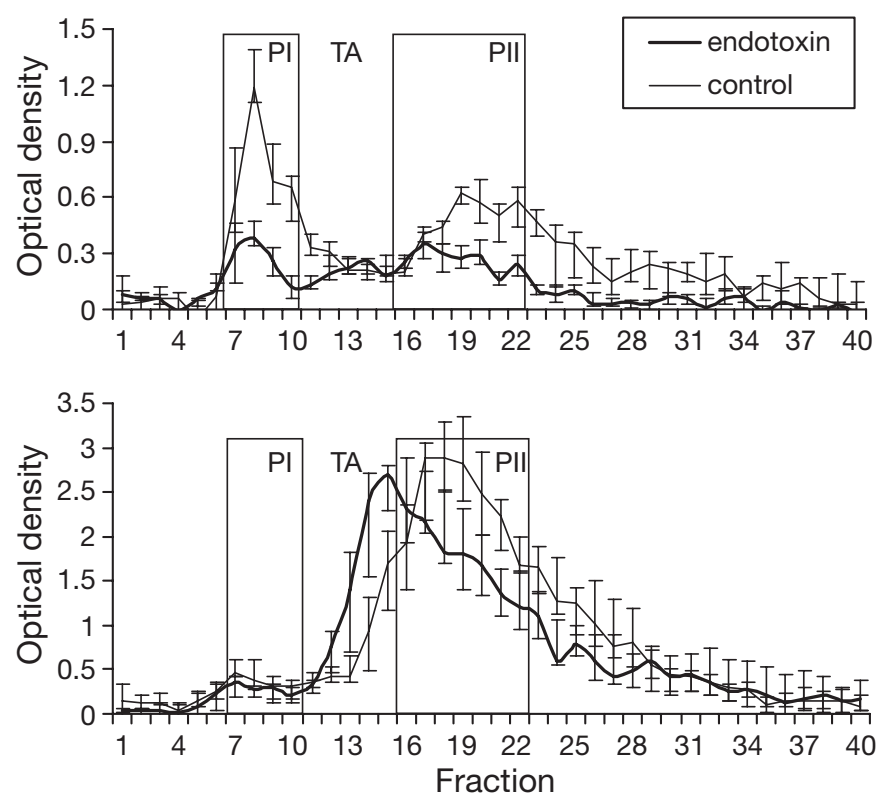

Day 3 p. appl.
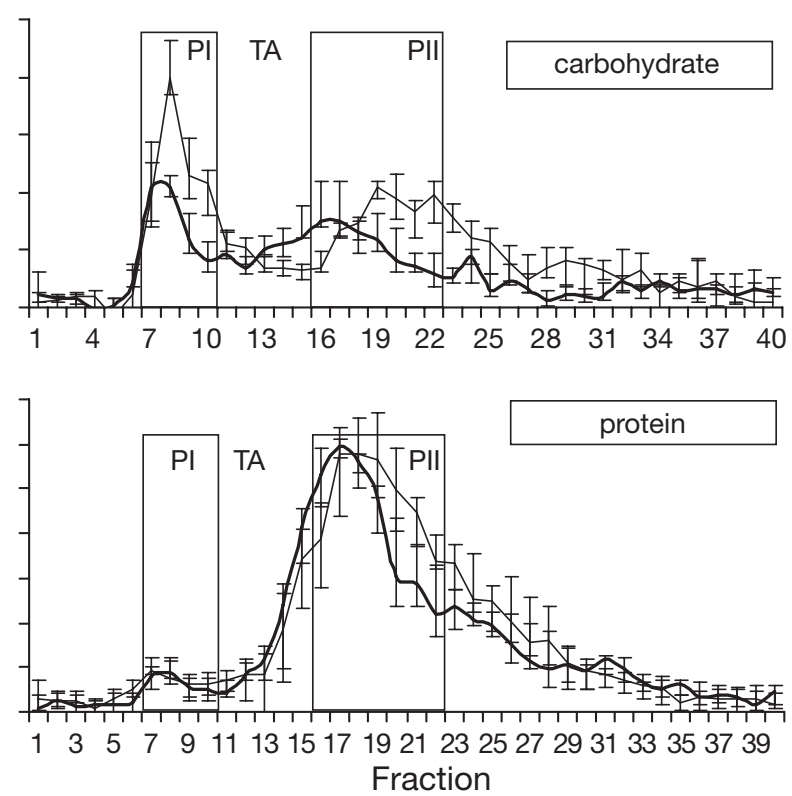

Fig. 4. Cyprinus carpio. Elution profiles of luminal glycoproteins from the gut $\left(\mathrm{g}^{-1}\right.$ gut weight) isolated on a Sepharose CL4B column (fraction volume: $1.3 \mathrm{ml}$ ) by Days 2 and 3 after a single, peroral application of endotoxin as described in 'Materials and methods'. p.appl.: post application. Carbohydrate content was monitored by periodic acid-Schiff reaction (PAS), and protein content by the Bradford-assay. Medians and 25th-75th percentiles of samples from 8 individuals are shown. PI: Peak I, glycoproteins exceeding $2000 \mathrm{kDa}$; PII: Peak II, elution fractions with glycoproteins between 70 and $700 \mathrm{kDa}$; TA: transition area, elution fractions with molecules between 700 and $2000 \mathrm{kDa}$ (control = oral application of phosphate buffered solution, pool 
(Table 2). For epithelial mucin glycoproteins, the calculated concentration ( $\mathrm{mg} \mathrm{g}^{-1}$ gut weight: CGC) was 2.5 times higher in PI $\left(0.25 \mathrm{mg} \mathrm{g}^{-1}\right)$ than in TA and PII (0.11 $\mathrm{mg} \mathrm{g}^{-1}$ and $0.09 \mathrm{mg} \mathrm{g}^{-1}$, respectively). For luminal mucin glycoproteins, $0.66 \mathrm{mg} \mathrm{g}^{-1} \mathrm{CGC}$ was found in PI, $0.27 \mathrm{mg} \mathrm{g}^{-1}$ in PII and $0.71 \mathrm{mg} \mathrm{g}^{-1}$ in TA (Table 2b).

In response to endotoxin, the amounts of isolated epithelial mucin glycoproteins changed as follows. Calculated by carbohydrate content, epithelial glycoproteins increased by Day 3 and Day 5 in PI, TA and in PII ( $p<0.05)$ (Table $2 a)$. The relative OD of protein content also increased in PI and TA by Days 3 and 5 $(p<0.05)$. In contrast, the relative OD of PII molecules decreased by Day 3 ( $p<0.05$, Table 2a).

In luminal glycoproteins, carbohydrate content decreased in PI, PII ( $p<0.05)$ and TA by Day 2. The protein content of luminal glycoproteins was reduced by Day 2 in PII ( $<<0.05)$ and PI.

Using the Limulus test, we measured endotoxin content of pooled mucin glycoprotein fractions from PI. Endotoxin content increased from a mean concentration of $4.53 \mu \mathrm{g}$ $\mathrm{g}^{-1}$ mucin in controls to $5.33 \mu \mathrm{g} \mathrm{g}^{-1}$ mucin (Day 1$)$. Subsequently, endotoxin content decreased to $3.59 \mathrm{\mu g} \mathrm{g}^{-1}$ mucin (Day 2) and to $3.56 \mu \mathrm{g} \mathrm{g}^{-1}$ mucin (Day 3).

\section{Terminal glycosylation pattern of isolated mucin glycoproteins}

The following lectins bound to the isolated glycoprotein: ConA (specificity for $\alpha-D-m a n n o s e)$, DBA (specificity for $\mathrm{N}$-acetyl- $\beta$-D-galactosamine), RCA (specificity for N-acetyl- $\alpha$-D-galactosamine) and SNA (specificity for Neuraminic- $\beta$-2-6-galactose). UEA I (specificity for $\alpha$-Dfucose) did not bind or had a weak binding reaction. The binding pattern of lectins applied to epithelial and luminal mucin glycoproteins is shown in Figs. 5 \& 6 .

As indicated by lectin binding, the glycosylation of separated glycoproteins changed by Days 1,2 and 3 in response to endotoxin. For epithelial mucin glycoproteins, these changes were generally manifested in mucin glycoproteins from PI. By Day 1, the amount of $\beta$-galactosamine had increased, while sialic acid decreased in mucin glycoproteins from TA. By Day 2, mannose and sialic acid had increased in mucin glycoproteins from PI, and $\beta$-galactosamine increased by Day 3 (Figs. 5 \& 6). It was only by Days 2 and 3 after endotoxin application that traces of fucose could be demonstrated in mucin glycoproteins of PI (data not shown).

For luminal glycoproteins, changes in glycosylation patterns generally appeared in molecules of PI and TA. By Day 1 after endotoxin application, the overall presence of mannose and sialic acid had decreased. In glycoproteins isolated on Day 2, mannose, sialic acid and $\beta$-galactosamine had increased, while by Day 3 the presence of all oligosaccharides analyzed had increased (Fig. 6). Glycoproteins containing fucose were not detected in PI or TA until Day 3 (in low quantities: 0.01 OD [0.01 -0.02]; data not shown) after LPS application.

\section{DISCUSSION}

The intestinal tract of fishes is colonized by large numbers of bacteria (Trust \& Sparrow 1974), and due to the ingestion of food particles covered in biofilm, there is a constant supply of additional microorganisms (Cahill 1990). Cells from the intestinal tissue are continually exposed to bacterial colonization. The mucus gel that covers the luminal surface of the intestine is thought to shield cells from noxes in gut contents (Neutra \& Forstner 1987). Little is known about how the mucus layer of fishes responds to bacterial influx and prevents bacterial invasion of intestinal tissues.

In mammalian systems, infection of the gut by pathogenic bacteria has been mimicked by oral application of endotoxin from the cell wall of gram-negative bacteria. In fish, many pathogenic and enteric bacteria are gram-negative (Trust \& Sparrow 1974, Jöborn et al. 1997, Bordas et al. 1998, O'Toole et al. 1999), which prompted us to apply endotoxin as a model substance. Because of poor knowledge on specific modifications of intestinal fish mucus, the aim of the present study was to describe reactions of intestinal mucosa and mucins of common carp to a single peroral application of endotoxin simulating strong bacterial colonisation.

Generally, intestinal and skin mucins of carp are similar to mucins of mammals. From the piscine intestinal mucosa, we isolated 2 different kinds of glycoproteins, viz. secreted glycoproteins from the surface of the intestinal epithelium (luminal glycoproteins) and epithelial glycoproteins stored in goblet cells. By gel filtration, a biphasic elution profile was obtained. Both preparations contained molecules $>2000 \mathrm{kDa}$ and between 70 and $700 \mathrm{kDa}$. Glycoproteins of high molecular weight were highly glycosylated, and the smaller glycoproteins carried less carbohydrate. A similar elution profile has been obtained in rats (Enss et al. 1996a,b).

Subsequent to secretion, mucin monomers form a polymer, which in the gut is a mixture comprising water, peptides, lipids and various serum and cellular macromolecules as well as indigenous bacteria (Neutra \& Forstner 1987, Bansil et al. 1995). Mucin glycoproteins are believed to mimic cellular carbohydrate structures and thus entrap microbial pathogens (Karlsson et al. 1991). In rats and mice, an increased intestinal mucin secretion occurs upon a single application of endotoxin (Enss et al. 1996a,b). This enhanced mucus production was thought to expel pathogenic bacteria and contribute to a protection of the epithelium (Enss 


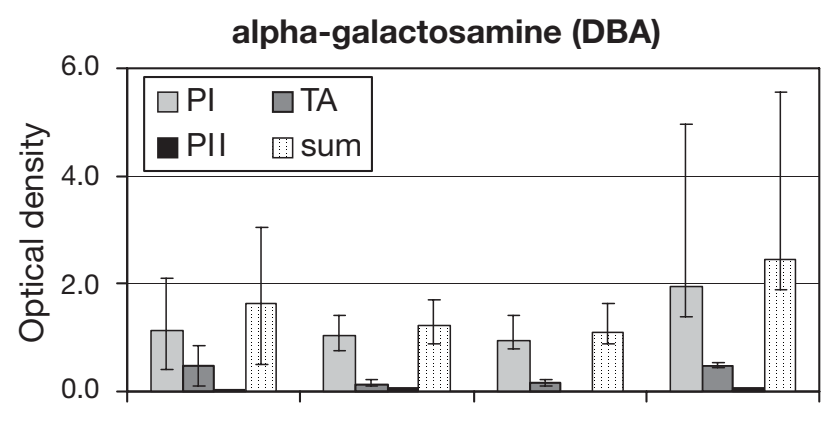

sialic acid (SNA)

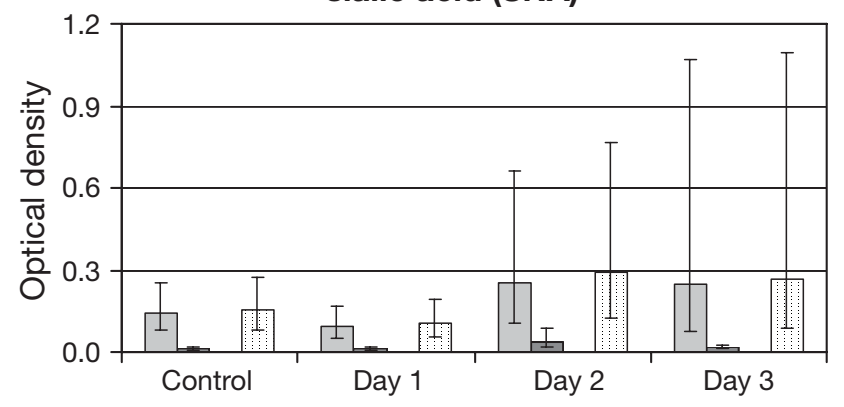

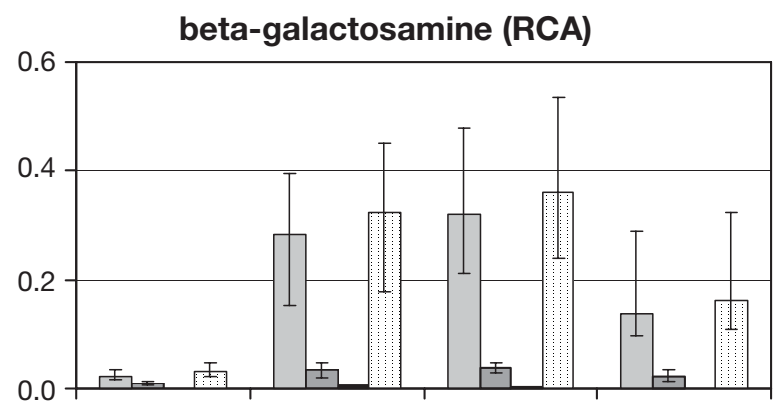

mannose (ConA)

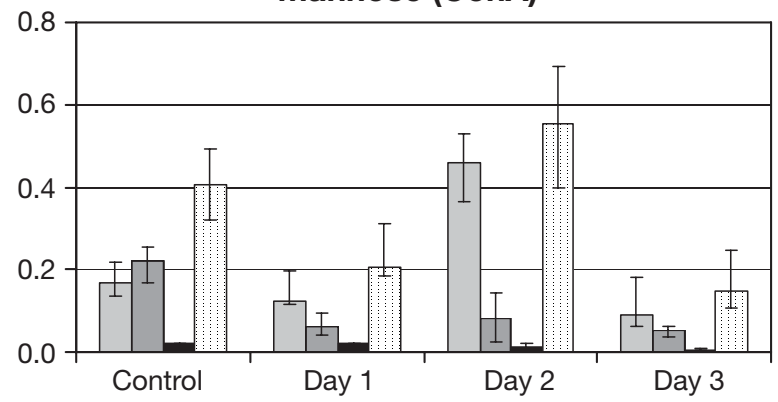

Fig. 5. Cyprinus carpio. Epithelial glycoproteins from the intestine. Semi-quantitative anaylsis of lectin binding to glycoproteins of control (pool from 2 fish by Days 2 and 3) and endotoxin-treated fish by Days 1, 2 and 3 after application of endotoxin. Binding specificity of lectins used: SNA, neuraminic acid; RCA, $\beta$-D-galactosamine; DBA, $\alpha$-D-galactosamine; ConA, $\alpha$-D-mannose. Lectins were applied to glycoproteins from the pooled fractions of Peak I (PI), TA (transition area), Peak II (PII) (displayed in this order and sum) from Figs. 1 \& 2. Medians and 25th-75th percentiles of measurements of material from 4 carp are shown (control: oral application of phosphate buffered solution). See Table 1 for definitions of stain acronyms
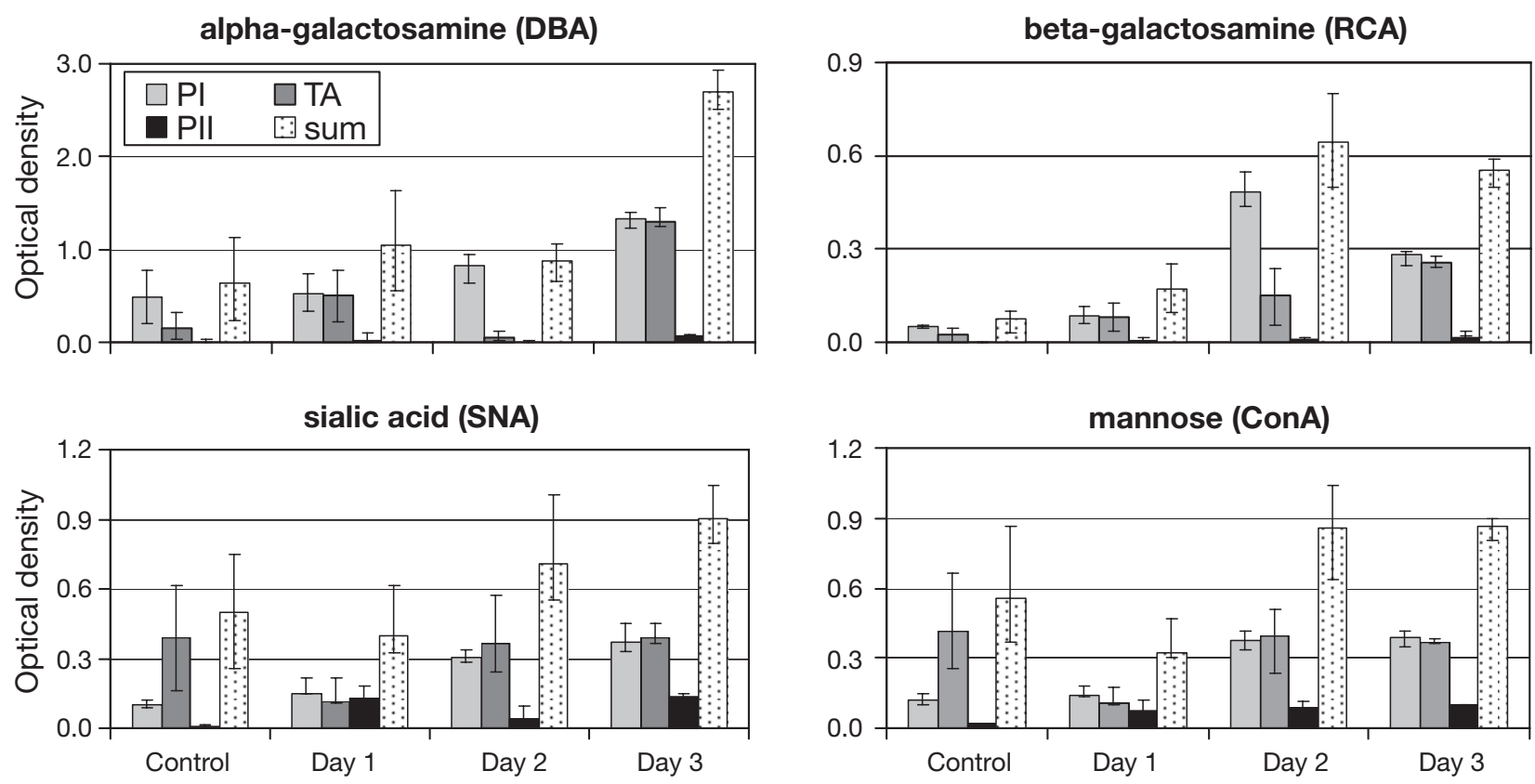

Fig. 6. Cyprinus carpio. Luminal glycoproteins from the intestine. Semi-quantitative anaylsis of lectin binding to glycoproteins of control (pool from 2 fish by Days 2 and 3) and endotoxin-treated fish by Days 1, 2 and 3 after application of endotoxin. Binding specificity of lectins used: SNA, neuraminic acid; RCA, $\beta$-D-galactosamine; DBA, $\alpha$-D-galactosamine; ConA, $\alpha$-D-mannose. Lectins were applied to glycoproteins from the pooled fractions of Peak I (PI), TA (transiition area), Peak II (PII) (displayed in this order and sum) from Figs. 1 \& 2 . Medians and 25th-75th percentile of measurements of material from 4 carp are shown (control: oral application of phosphate buffered solution). See Table 1 for definitions of stain acronyms 
et al. 1995, 1996a,b). In mammalian species, endotoxin (as an integrated part of bacterial membranes) induces inflammatory reactions up to endotoxic shock level. Fish, however, are resistant to endotoxic shock as a result of differences in the cellular mechanisms of endotoxin recognition (Iliev et al. 2005). Thus, similar to many in vitro studies on leucocytes of different fish species, e.g. carp, extremely high concentrations of LPS (in comparison to mammals) are used to demonstrate probable effects on intestinal mucosa (Pelegrin et al. 2002, MacKenzie et al. 2003, Stafford et al. 2003, Zou et al. 2003, Hirono et al. 2004).

In the present study, the oral application of endotoxin to carp induced an enhanced secretion of mainly fully developed mucins (PI) by Day 1, which led to a substantial loss of luminal, adherent mucus by Day 2 (Fig. 4, Table 2b). Increased amounts of glycoproteins in fractions from the TA indicates a stimulated secretion of smaller, immature mucins. Tse \& Chadee (1991) described an initial secretion of incompletely synthesized mucins, and postulated an incomplete glycosylation with a reduced amount of sialic-acid related to enteric infections. This view was supported by the results of the present study, which showed that by Day 1, epithelial and luminal mucin glycoproteins had a reduced content of sialic-acids (Figs. 5 \& 6). During stepwise assembly of mucin oligosaccharides, terminally linked sialic-acids shield mucin glycoproteins from degradation by bacterial enzymes (Forstner \& Forstner 1994, Forstner 1995, Aristoteli \& Wilcox 2003, Schauer 2004).

In controls, a positive Limulus test seemed to indicate endotoxin integrated into the cell walls of the autochthonal flora. An increasing endotoxin content of mucins by Day 1 subsequent to oral application may be interpretated as an adhesion of endotoxin to fully developed mucin glycoproteins. Induced loss of mucin glycoproteins also led to a decreased amount of endotoxin (Days 2 and 3).

Endotoxin-stimulated secretion of intestinal glycoproteins in carp might also act as a first intestinal clearance mechanism for bacterial noxes. Subsequent to the luminal loss of mucin glycoproteins, epithelial mucin glycoprotein content increased by Days 3 and 5, indicating that an endotoxin stimulus may also induce a new biosynthesis of mucins.

Many intestinal parasite infections are associated with pseudofaeces, which in clinical studies are often regarded as a common sign for these intestinal infections (Wildgoose 2001). The loss of luminal mucin glycoproteins in response to endotoxin stimulus confirms the view that pseudofaeces may also be interpreted as a support/signal for the elimination of intestinal bacterial noxes. However, the massive expulsion of mucus glycoproteins results in a thinner mucus cover of the intestinal epithelium (Fig. 5, Day 2). This might facilitate an increased risk of bacterial invasion after bacterial dissemination in the gut. However, this thinner mucus layer might promote the uptake of oral vaccines. Thus, further studies should determine whether an endotoxin application prior to a delivery of an oral vaccine may reduce muco-adherence of vaccines and, in consequence, increase their absorption.

The glycosylation of piscine mucins takes place principally in 5 monosaccharides, fucose, sialic acid, mannose, $N$-acetyl- $\alpha$-galactosamine and $N$-acetyl- $\beta$-galactosamine (Fletcher et al. 1976, Alexander \& Ingram 1992, Shephard 1994). During the present study, most changes in glycosylation pattern were seen by Days 1 through 3 after application of endotoxin. In histochemical stainings of the gut sections, these changes were not very obvious, but they were evident in mucus samples examined by biochemical techniques. Therefore, biochemical methods seem to be more suitable for the characterization of intestinal glycoproteins than histochemical techniques. In agreement with the findings of Fiertak \& Kilarski (2002), our study of carp mucus demonstrated (in general) no fucose, but large amounts of $N$-acetyl- $\alpha$-galactosamine and $N$-acetyl- $\beta$ galactosamine (via DBA and RCA) as main terminal residues. However, by Day 3 after the stimulus, a faint positive lectin reaction for fucose was measured. General changes in the glycosylation pattern and the occurrence of fucose in intestinal mucins in response to endotoxin provided evidence for a second microbial clearance mechanism, viz. altered glycosylation can enhance bacterial adherence. This mechanism may be seen as an adaptive clearance and protection system. In contrast to mammalian systems, this microbial clearance system seems to be mediated mainly by local intestinal reactions and not by systemic responses of leucocytes. The endotoxin stimulus did not induce an obvious cell infiltration into gut tissue.

In summary, a peroral endotoxin stimulus altered the intestinal secretion and composition of mucin glycoproteins in carp, obviously linked to a simultaneous increase in their biosynthesis. The mucosal system seems to provide an adaptive removal mechanism for bacterial noxes by increased secretion of mucins with a modified glycosylation pattern. This may lead to altered bacterial adherence with a combined cleansing effect (Carlstedt et al. 1985, Karlsson et al. 1991, Bordas et al. 1998, Abraham et al. 1999, Moncada et al. 2003). Changes in mucin synthesis and secretion seem to be mediated primarily by local reactions in the gut and not by systemic leucocyte mechanisms. Consequently, the formation of pseudofaeces in fish (that in clinical diagnoses are a common indicator for intestinal parasitical infections) may also be interpreted as an indication of the presence of strong bacterial noxes. 
Acknowledgements. We are thankful for the generous technical support provided by $\mathrm{H}$. Hedrich, Institute for Laboratory Animal Science and Animal Facility, Medical School Hannover, J. Kamphues, Department of Animal Nutrition and U. Neumann, Clinic for Poultry, University of Veterinary Medicine Hannover. The authors acknowledge financial support by the European Community's Improving Human Potential Programme under contract [HPRN-CT-2001-00241], [PARITY]

\section{LITERATURE CITED}

Abraham SN, Sharon N, Ofek I (1999) Adhesion of bacteria to mucosal surfaces. In: Gallin JI, Fauci AS (eds) Mucosal immunology. Academic Press, San Diego, CA, p 31-40

Alexander JB, Ingram GA (1992) Noncellular nonspecific defence mechanisms of fish. Annu Rev Fish Dis 2:249-279

Aristoteli LP, Willcox MD (2003) Mucin degradation mechanisms by distinct Pseudomonas aeruginosa isolates in vitro. Infect Immun 71:5565-5575

Bansil R, Stanley E, LaMont JT (1995) Mucin biophysics. Annu Rev Physiol 57:635-657

Bordas MA, Balebona MC, Rodriguez-Marato JM, Borrego JJ, Morinio A (1998) Chemotaxis of pathogenic Vibrio strains towards mucus surfaces of gilt-head sea bream (Sparus aurata L.). Appl Environ Microbiol 64:1573-1575

Bosi G, Shinn AP, Giari L, Simoni E, Pironi F, Dezfuli BS (2005) Changes in the neuromodulators of the diffuse endocrine system of the alimentary canal of farmed rainbow trout, Oncorhynchus mykiss (Walbaum), naturally infected with Eubothrium crassum (Cestoda). J Fish Dis 28:703-11

Bradford MM (1976) A rapid and sensitive method for the quantitation of microgram quantities of protein utilizing the principle of protein-dye binding. Anal Biochem 72:248-254

Brooks SA, Leathem AJ, Schumacher U (1997) Lectin histochemistry - a concise practical handbook. Bios Scientific Publishers, Oxford

Cahill MM (1990) Bacterial flora of fishes: a review. Microbiol Ecol 19:21-41

Carlstedt I, Sheehan JK, Corfield AP, Gallagher JT (1985) Mucous glycoproteins, a gel of a problem. Essays Biochem 20:40-76

Dezfuli BS, Pironi F, Giari L, Domeneghini C, Bosi G (2002) Effect of Pomphorhynchus laevis (Acanthocephala) on putative neuromodulators in the intestine of naturally infected Salmo trutta. Dis Aquat Org 51:27-35

Dubois M, Hamilton KA, Rebers PA, Smith F (1956) Colorimetric method for determination of sugars and related substances. Anal Chem 28:350-356

Enss ML, Grosse-Siestrup H, Schmidt-Wittig U, Gärtner K (1992) Changes in colonic mucins of germfree rats in response to the introduction of a 'normal' rat microflora. J Exp Anim Sci 35:110-119

Enss ML, Schmidt-Wittig U, Heim HK, Sewing KF (1995) Prostaglandin E2 alters terminal glycosylation of high molecular weight glycoproteins released by pig gastric mucins. Prostaglandins Leukot Essent Fatty Acids 52:333-340

Enss ML, Müller H, Schmidt-Wittig U, Kownatzki R, Coenen M, Hedrich HJ (1996a) Effects of perorally applied endotoxin on colonic mucins of germfree rats. Scan J Gastroenterol 31:668-674

Enss ML, Schmidt-Wittig U, Müller H, Mai UEH, Coenen M, Hedrich HJ (1996b) Response of germfree rat colonic mucous cells to peroral endotoxin application. J Exp Anim Sci 38:58-65
Fiertak A, Kilarski WM (2002) Glycoconjugates of the intestinal goblet cells of four cyprinids. Cell Mol Life Sci 10:1724-1733

Fletcher TC, Jones S, Reid L (1976) Identification of glycoproteins in goblet cells of epidermis and gill of plaice (Pleuronectes platessa L.), flounder (Platichthys flesus (L.) and rainbow trout (Salmo gairdneri Richardson). Histochem J 8:597-608

Forstner GG (1995) Signal transduction, packaging and secretion of mucins. Annu Rev Physiol 57:585-605

Forstner GG, Forstner JF (1994). In: Johnson LR (ed) Physiology of gastrointestinal tract. Raven Press, New York, p 1255-1283

George PV, Nadakal AM (1981) Observations on the intestinal pathology of the marine fish, Rachycentron canadus (Guenther) infected with the acantocephalid worm, Serrasentis nadakali. Hydrobiologica 78:59-62

Hirono I, Takami M, Miyata M, Miyazaki T, Han HJ, Takano T, Endo M, Aoki T (2004) Characterization of gene structure and expression of two toll-like receptors from Japanese flounder, Paralichthys olivaceus. Immunogenetics $56: 38-46$

Iliev DB, Roach JC, Mackenzie S, Planas JV, Goetz FW (2005) Endotoxin recognition: in fish or not in fish? FEBS Lett 579:6519-6528

Jöborn AJC, Olsson A, Westerdahl PL, Conway, Kjelleberg S (1997) Colonisation in the fish intestinal tract and production of inhibitory substances in intestinal mucus and faecal extracts by Carnobacterium $s p$. strain K1. J Fish Dis 20:383-392

Karlsson KA, Angström J, Teneberg S (1991) Characteristics of the recognation of host cell carbohydrates by viruses and bacteria. In: Waldström T (ed) Molecular pathogenesis of gastrointestinal infections. Plenum Press, New York, p 9-21

MacKenzie S, Planas JV, Goetz FW (2003) LPS-stimulated expression of a tumor necrosis factor-alpha mRNA in primary trout monocytes and in vitro differentiated macrophages. Dev Comp Immunol 27:393-400

Moncada DM, Kammanadiminti SJ, Chadee K (2003) Mucin and toll-like receptors in host defense against intestinal parasites. Trends Parasitol 19:305-311

Morita T, Harada T, Nakamura S, Iwanaga S, Niwa M (1978) Horseshoe crab (Tachypleus tridentatus) clotting enzyme: a new sensitive assay method for bacterial endotoxins. Jpn J Med Sci Biol 31:178-181

Neutra MR, Forstner JF (1987) Gastrointestinal mucus: synthesis, secretion, and function. In: Johnson LR (ed) Physiology of the gastrointestinal tract. Raven Press, New York, p 975-1009

O'Toole R, Lundberg S, Fredriksson S, Jansson A, Nilsson B, Wolf-Watz H (1999) The chemotactic response of Vibrio anguillarum to fish intestinal mucus is mediated by combination of multiple mucus components. J Bacteriol 181:4308-4317

Pearse AGE (1972) Histochemistry, theoretical and applied, 3rd edn, Vol 1, 2. Churchill-Livingstone, Edinburgh

Pelegrín P, García-Castillo J, Mulero V, Meseguer J (2002) Interleukin-1, isolated from a marine fish reveals up-regulated expression in macrophages following activation with lipopolysaccharide and lymphokines. Cytokine 16:67-72

Perez-Vilar J, Hill R (1999) The structure and assembly of secreted mucins. J Biol Chem 274:31751-31754

Raetz CRH (1990) Biochemistry of endotoxins. Annu Rev Biochem 59:29-170

Raetz CRH, Whitfield C (2002) Lipopolysaccharide endotoxins. Annu Rev Biochem 71:635-700 
Schauer R (2004) Sialic acids: fascinating sugars in higher animals and man. Zoology 107:49-64

Shephard KL (1994) Functions for fish mucus. Rev Fish Biol Fish 4:401-429

Stafford JL, Ellestad KK, Magor KE, Belosevic M, Magor BG (2003) A toll-like receptor (TLR) gene that is up-regulated in activated goldfish macrophages. Dev Comp Immunol 27:685-698

Trust TJ, Sparrow RAH (1974) The bacterial flora of the alimentary tract of fresh water salmonid fishes. Can J Microbiol 20:1219-1228

Tse SK, Chadee K (1991) The interaction between intestinal mucus glycoproteins and enteric infections. Parasitol Today 7:163-172

Urlaub U (1998) Reactions of the intestinal mucosa of

Editorial responsibility: David Bruno,

Aberdeen, UK germfree and colonized mice to a single peroral application of endotoxin with special consideration of its secreted mucins. Dissertation, University of Veterinary Medicine Hannover

Wiegertjes GF, Stet RJM, van Muiswinkel WB (1995) Divergent selection for antibody production to produce standard carp (Cyprinus carpio L) lines for the study of disease resistance in fish. Aquaculture 137:257-262

Wildgoose WH (2001) Internal disorders. In: Wildgoose WH (ed) BSAVA manual of ornamental fish, 2nd edn. British Small Animal Veterinary Association, Gloucester, p 132-134

Zou J, Secombes CJ, Long S, Miller N, Clem LW, Chinchar VG (2003) Molecular identification and expression analysis of tumor necrosis factor in channel catfish (Ictalurus punctatus). Dev Comp Immunol 27:845-858

Submitted: December 5, 2006; Accepted: May 2, 2007 Proofs received from author(s): July 17, 2007 